\title{
In the Search for Impact and Relevance: A Design Science Approach
}

\author{
Tillman Boehme and Alberto Ordigoni \\ University of Wollongong, Wollongong, Australia
}

tbohme@uow.edu.au ao002@uowmail.edu.au

\author{
Eric Deakins \\ Waikato University, New Zealand
}

edeakins@waikato.ac.nz

\begin{abstract}
In spite of more than 30 years of academic publications in (supply chain) management, a significant gap between theory and practice remains. Due to the increasing concern that research is not relevant for practice, scholars have started addressing the issue of academic relevance. On the hand scholars argue that the issue can be identified as a 'knowledge transfer' problem, thus research findings are relevant for practice but are not produced in a form that can be easily applied by practitioners. On the other hand scholars argue that it is a 'knowledge creation' problem, in other words research findings are not meaningful for practice due to the closed and autoreferential nature of the system of Science and the system of Practice. This paper argues for a third approach, namely 'knowledge adaptation' problem, to tackle the issue of impact and relevance via a well proven supply chain diagnostic methodology. The robust mixed-methods approach known as Quick Scan Audit Methodology can yield two results: (1) enhancing scholars' understanding of how supply chain theories are (or can be) applied in practice which leads to the adaption and extension of management theory; (2) translating theories, supporting them in implementing improvement programs within their organisations.
\end{abstract}

Keywords. Mixed method, triangulation, supply chain audit, quick scan, audit, field research, design science

\section{Introduction}

Despite more than 30 years of academic publication, a significant gap between (supply chain) management theory and practise still remains. As a result, many scholars report that few compa-

Material published as part of this publication, either on-line or in print, is copyrighted by the Informing Science Institute. Permission to make digital or paper copy of part or all of these works for personal or classroom use is granted without fee provided that the copies are not made or distributed for profit or commercial advantage AND that copies 1) bear this notice in full and 2) give the full citation on the first page. It is permissible to abstract these works so long as credit is given. To copy in all other cases or to republish or to post on a server or to redistribute to lists requires specific permission and payment of a fee. Contact Publisher@InformingScience.org to request redistribution permission. nies are actually engaged in extensive and advanced (supply chain) management practises (Halldorsson, Larson \& Poist, 2008; Towill, Childerhouse \& Disney, 2002; Zailani \& Rajagopal, 2005).

For instance, Fawcett and Magnan (2002) carried out a multi-method research approach involving both surveys and case study interviews in the USA. Their findings (Fawcett \& Magnan, 
2002) revealed that supply chain practises seldom resembled supply chain management theories and only very few companies have truly begun to establish a supply chain management (SCM) culture. However, companies which started establishing a SCM culture have begun to map their supply chain, analyse value propositions and core competencies, and evaluate the appropriateness of existing and future supply chain relationships (Fawcett \& Magnan, 2002). In a similar study, Towill, Childerhouse and Disney (2002) carried out detailed case studies on 20 supply chains from the European automotive sector; a sector well-known for its advanced supply chain practises (e.g. Toyota Production System). They found that $80 \%$ of the sample struggled to be internally integrated, with the remainder advancing further, towards external integration. This study was later extended to an international comparison study focusing on companies in the UK, Thailand, New Zealand, and Germany; however no improvement was forthcoming.

Recently, also quantitative studies report the poor application of supply chain management concepts (Poirier \& Quinn, 2003; Zailani \& Rajagopal, 2005). Zailani and Rajagopal (2005) report that companies are still in their infancy stage when it comes to supply chain management and integration with customers and suppliers. Although SCM is a desirable concept, practitioners seem to struggle with its successful application. In addition to these studies of the limits of applying supply chain management concepts in practice, another stream of management scholars focused on self-reflection and concluded that many management theories are un-implementable (Beer, 2001). So the question remains:

- How can (supply chain) management science increase their batting average in regards to implementable theories?

The paper is structured as follows. In the first section of the paper, a literature review discussing how scholars have addressed the issue of academic relevance will be presented. In the second section the Quick Scan Audit Methodology will be briefly explained. In the third section the link between QSAM and Design Science will be analysed. In the last section, QSAM will be discussed as a means to bridge the gap between theory and practice.

\section{Literature Review}

Traditional (supply chain) management researchers tend to belong to the positivist paradigm (Eisenhardt, 1989). This approach is still very prevalent in today's management research. For example, Mentzer and Kahn (1995) reviewed the articles published in the Journal of Business Logistics between 1978 and 1993 and identified that $50 \%$ of all publications were survey based, whereas case study research accounted only for 3.2\%. In 2005, Kotzab followed up on Mentzer and Kahn's study and found that $40 \%$ of all publications were still survey based. Also, in a study similar covering the period from 1990 and 2005, Seuring (2005) focused on two distinct areas of supply chain management: (1) sustainable supply chain management, and (2) supply chain performance management. Seuring's study (2005) revealed that the topic of supply chain performance management is dominated by survey methods ( $42 \%)$, whereas case study research only accounts for $11 \%$. Finally, Carter and Ellram (2003) studied 35 years of publication in the Journal of Supply Chain Management. The scholars identified that the dominant type of primary research design employed is mail survey (approximately 60\%), while case study research only accounted for approximately 18\% (Carter \& Ellram, 2003). The dominance of surveys indicates that a positivist paradigm and, thus, mainly quantitative methods, are preferred by supply chain management researchers. However, the relevance of the theories developed using positivist approaches are often questioned by practitioners (Beer, 2001).

Hence, recent developments in management literature are seeking for methods to bridge the gap between theory and practice (Cascio 2007; Hambrick 2007). The topic has been discussed in several special issues of academic journals such as the Journal of Management Studies (Clark \& Fin- 
cham, 2009) and Organization Studies (Jelinek, Romme \& Boland, 2008). Traditionally, the problem has been framed either as a 'knowledge transfer problem' (lost in translation) or a 'knowledge production problem' (lost before translation) (Shapiro, Kirkman \& Courtney, 2007). In the first case (lost in translation), the main assumption is that practical knowledge derives in part from research knowledge but practitioners hardly adopt research findings in applied scenarios (Tranfield, Denyer \& Smart, 2003). According to this approach (van de Ven \& Johnson, 2006), research knowledge is relevant for practice but is not produced in a form that can be easily applied in practice because academics rarely engage in transferring the knowledge they produce (Beer, 2001). In the second case (lost before translation), the main assumption is that 'scientific results are unconnectable to and therefore untranslatable for practice' (Kieser \& Liener, 2009, p. 517). In particular, Kieser and Liener's (2009) argument stems from Luhmann's system theory (Luhmann, 1995, 2005) and points out that science and practice are two separate systems that operate according to separate logics and rules. According to Kieser and Liener (2009) science is a closed system based on true/false code whose final scope is the pursuit of truth. Science's purpose of researching truth and critical purity excludes it from the realm of practice and thus research findings are not relevant for practice (Clark \& Fincham, 2009). Nonetheless, Kieser and Liener (2009) do not deny the possibility of a useful exchange between theory and practice by means of 'facilitators who are able to apply scientific knowledge in flexible ways to problem situations in practice' (Kieser \& Liener, 2009, p. 528).

However, both approaches (knowledge transfer and knowledge creation) present some shortcomings. On the one hand, the 'knowledge transfer' approach is based on an oversimplified view of knowledge reproduction that was defined by van De Ven and Johnson (2006, p. 805) as a 'trickle down view of the knowledge supply chain'. In this view, knowledge can be easily transferred in a linear fashion from academics, to students, consultants and practitioners (van de Ven \& Johnson, 2006). On the other hand, the 'knowledge production' approach, and in particular Kieser and Liener's position (2009) is based on the claim that all sciences, including social sciences such as management are closed systems based on a true/false code. Nevertheless, as Rousseau and Hodgkinson (2009) point out, firstly there is no empirical support to Kieser and Liener's definition of science and secondly, this definition does not take into account that social phenomena are compounds of formal regulations, codes of conduct, mutual co-ordination and structures of cooperation (Kay, 2003). As a result, management research, education and practice are dynamic and adaptive rather than closed, separate systems (Rousseau \& Hodgkinson, 2009).

A third way to tackle the problem has been discussed by Rasche and Behnam (2009). The authors argue that research relevance cannot be achieved by means of a direct application of scientific knowledge into practice since scientific knowledge needs to be modified and adapted by the system of practice itself (Rasche \& Behnam, 2009). Practitioners can make sense of theory by modifying, extending and reconstructing scientific knowledge within their organizations to legitimize their courses of action (Rasche \& Behnam, 2009). This approach leans towards the concept of design science developed by Simon (1967). Design science is based on the question, 'Will it work better?' (Jelinek, Romme \& Boland, 2008, p. 317) and aims to identify methodologies that can design artefacts which lead to more effective management practice (Starkey, Hatchuel, \& Tempest 2009). A summary of the three approaches is shown in Figure 1. 

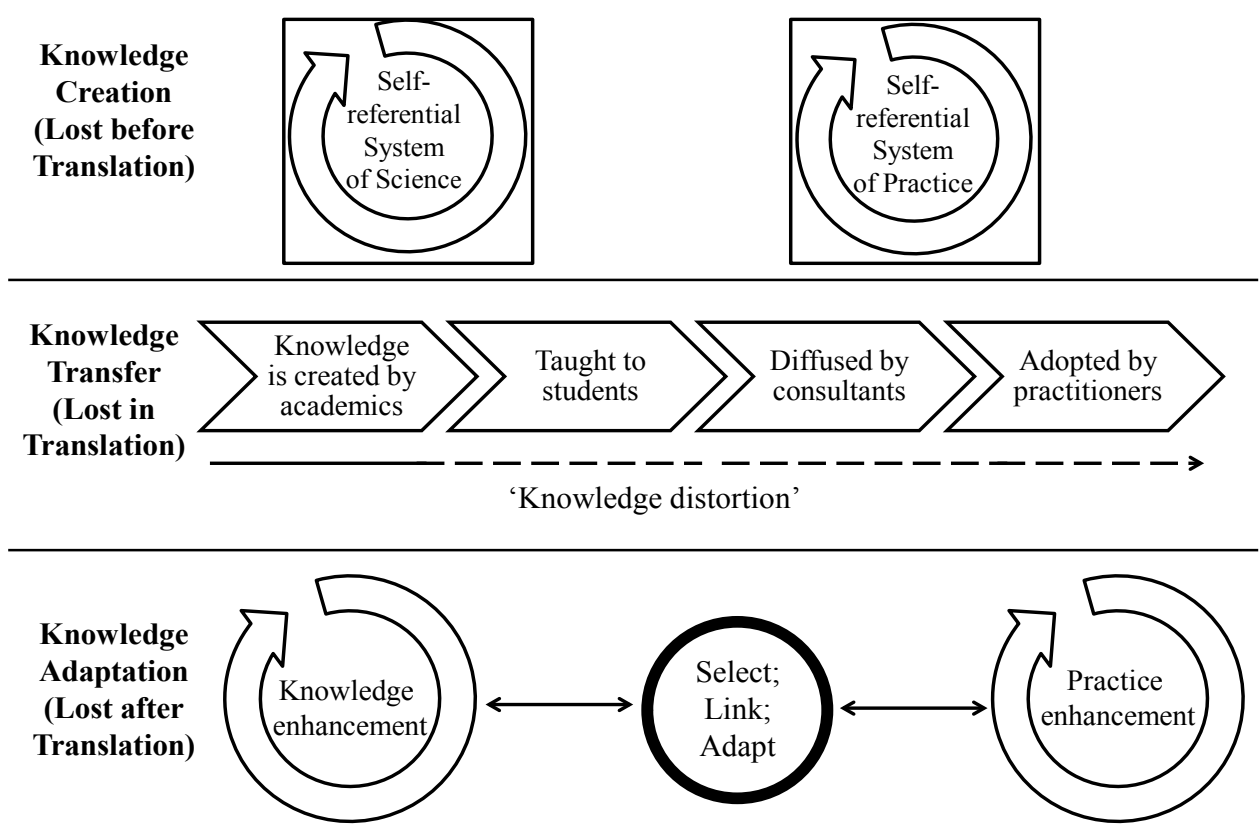

Figure 1: A summary of the three epistemological approaches

Adapted from: (Rasche \& Behnam, 2009; van de Ven \& Johnson, 2006).

Next, a supply chain diagnostic termed Quick Scan Audit Methodology is presented that is extending the knowledge adaptation loop to fulfil the requirement of design sciences.

\section{Design Sciences via Quick Scan Audit Methodology}

In the early 1990s a procedure known as the Quick Scan Audit Methodology (QSAM) originated from the Logistics Systems Dynamics Group at Cardiff University. This was originally created to describe and explain the complexities of a 'messy' European automotive supply chain environment via the application of multiple, site-centred data collection methods (Towill, Childerhouse, \& Disney, 2002).

Arguably the concept of supply chain management originates from a systems perspective (Christopher, 1998), in which the idea of a system is generally expressed as encompassing interconnected components separated from their environment by a system boundary. This is also in line with Näslund's (2002) description of modern logistics, the author argues that modern logistics is based on holistic, systemic thinking which in turn requires multi-disciplinary and crossfunctional approaches. Although QSAM continues to evolve, its underlying 'systems thinking' approach has remained the same. Fawcett, Ellram and Ogden (2007) provide the following definition of this approach:

Systems thinking is the holistic process of considering both the immediate local outcomes and the longer-term system-wide ramification of decisions. Whereas traditional functional thinking seeks the local optimum - often at the expense of the overall system's performance - systems thinking aligns efforts; getting everyone to pull in the same direction. (pp. 74-75)

QSAM utilises a structured modelling framework that can be traced back to the original concept of a manufacturing system developed by Parnaby (1979), which was exploited by Edgehill, Ols- 
mats and Towill (1988) within a UK industrial context. A key characteristic of this framework is that it endeavours to achieve an optimum compromise between qualitative and quantitative methods of management theory research, by making maximum use of resources (primarily) in fieldbased activities in the search for 'meaning of evidence' (Eisenhardt, 1989). In practise, this approach mixes qualitative and quantitative methods when seeking to triangulate information sources (Beach, 2001; Berry, 1995; Jick, 1979).

The QSAM developers had also realised that supply chain specific issues need to be combined with related management practises (e.g. Marketing, Strategic Management, Human Resources; to name a few) as well as industrial norms and environmental settings (Näslund, 2002). This allows researchers to gain a complete 'rich' picture of the focal company situation (including its setting in the wider supply chain) and lends a second theoretical underpinning termed contingency theory (Lawrence, 1967; Thompson, 1967). Contingency theory argues that there is no single optimal organisational design because the environment and the industrial sector within which the organisation operates will inevitably shape structures, end-to-end processes, and value streams (Scott \& Cole, 2000). This suggests that companies should match their structures and processes to the environment in order to maximise performance (Flynn, 2010; Lawrence, 1967).

Theoretical refinement of QSAM required several years of brainstorming, debate, experimentation, and triangulation before the current format emerged. In fact, QSAM brings together four key stakeholders (each with their own respective interests): the Host organisation (What's in it for me?); The Business Community (What can we learn from them?); the Analytic Auditors (How do we rate this supply chain?); and the Research Community (What new knowledge is revealed?). The four parties involved are shown in Balanced Scorecard format in Figure 2, which also indicates four feedback loops.

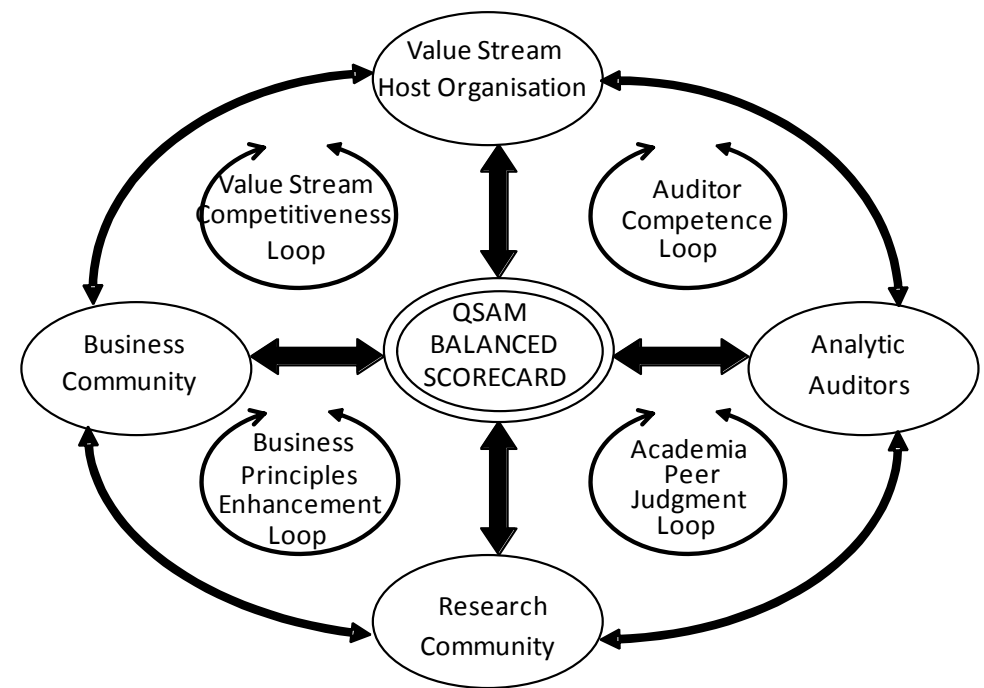

Figure 2: QSAM Balanced Scorecard - Bringing together four interested parties. Source: (Böhme, Childerhouse, Deakins, \& Towill, 2012)

The Auditor Competence Loop is critical, requiring that the auditors are well trained, focused, observant and capable of participation as a member of an academic-industry team. In particular they require an inquisitive mind, good time management skills, should not accept data or opinion at face value, and should aim to achieve good data triangulation via different data sources. The Value Stream Competitiveness Loop codifies (and ranks) measures of supply chain performance against external benchmarks. An interesting consequence of accumulating QSAM audit results is that they too provide a rich benchmarking source in their own right. The Academia Peer Judge- 
ment Loop is where the quality of the final research output is assessed. Finally, there is the Business Principles Enhancement Loop whereby new knowledge influences real work practices. At the same time the need to keep the team anchored into an environment where industrial performance may be audited (and moreover understood) remains paramount.

\section{QSAM Process}

The research/audit process is typically undertaken by a team of experienced researchers assisted by host organisation supply chain 'players' in a structured approach designed to fit around the limited time available to busy managers and staff. For example, when the aim of the QSAM is to assess the level of integration of a particular value stream, typically 4-5 researchers will spend six days on site closely assisted by an in-house business champion (Böhme, Childerhouse, Deakins, Potter, \& Towill 2008). Figure 3 illustrates the simplified process flow diagram of such a QSAM audit.

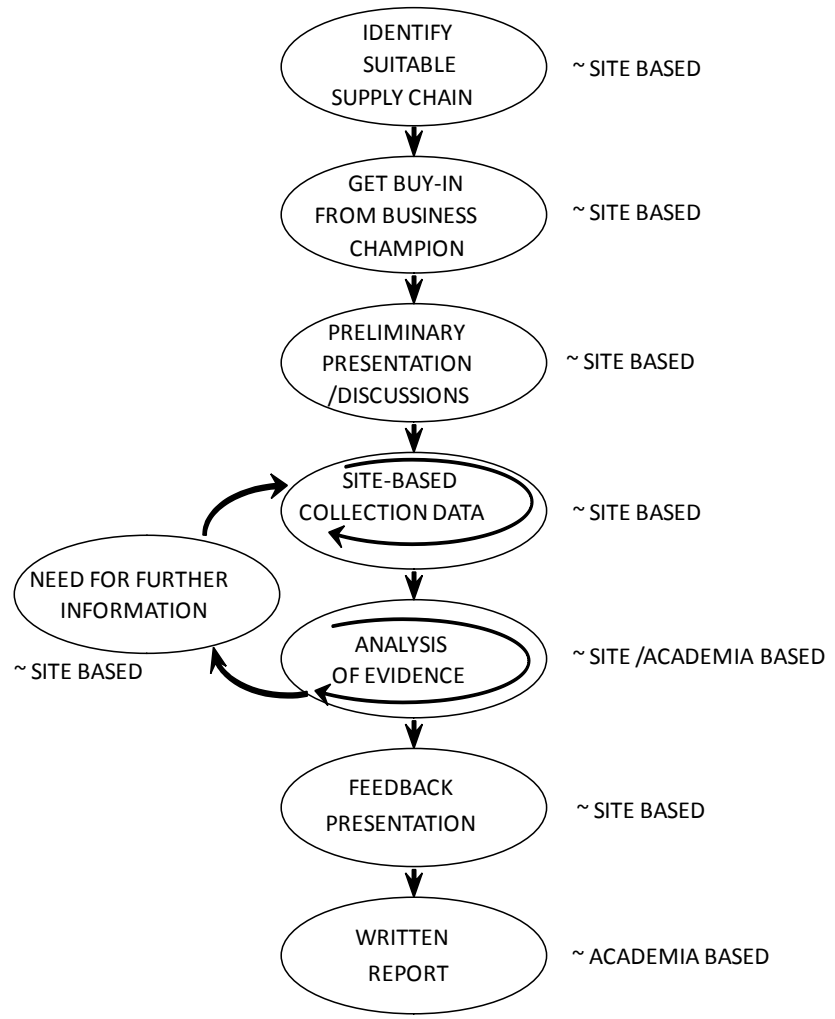

Figure 3: Simplified QSAM Process Flow Diagram

Source: (Böhme, Childerhouse, Deakins, \& Towill, 2012)

Judgments regarding individual supply chains are based on a combination of case study-type metrics and statistically significant data. In seeking to maintain this standard, the researchers aim to exploit knowledge from as many data sources as possible. The figure can only hint at the intensity of the various site-based activities which are designed to achieve maximum information volume and fidelity. A QSAM is inevitably both time and resource constrained. Although data collection and analysis lies at its heart, front-end and back-end activities help to ensure that all participants 'sing from the same hymn sheet', and that the host organisation receives maximum benefit from the experience.

Continuing with the same example, audit data would be collected from four distinct sources to facilitate methodological triangulation and increase internal validity: process maps, attitudinal and quantitative questionnaires, semi-structured interviews and examination of archival infor- 
mation. Process mapping provides a detailed walk-through and understanding of the material and information flows for one or more selected value streams. Questionnaires are used to gain overall information of the focal organisation including: key customers, suppliers, production volumes, product variants, and company structure. Semi-structured interviews are conducted with a crosssection of senior and middle managers from each functional division and cover their role, perceived problems and difficulties according to their respective position in the supply chain process map. The final type of data collection is examination of archival data; this being perceived to be relatively unbiased and able to provide historical factual data from respondents (Flynn, Sakakibara, Schroeder, Bates, \& Flynn, 1990). The goal of the various data collection techniques is to fully understand the phenomenon being studied, and the accumulation of multiple supporting sources of evidence helps to assure that the facts being collected are indeed correct (Meredith, 1998).

When codified the large volume of collected data is used to explain the process, supply, control and demand sources of uncertainty that indicate the overall integration level of a supply chain (Childerhouse \& Towill, 2002). A most critical element of a QSAM audit study concerns how data extracted from the supply chain system is analysed using systems thinking principles. Causeeffect analysis is utilised to reveal: (a) the 'major pain(s)' the company is feeling (symptoms of the underlying problems); (b) the supply chain/ process integration barriers; and, (c) the root (initiating) causes of the identified major pain(s). Cause-effect analysis fulfils the integrated/systems thinking perspective requirement of Edwards and Ram (2006) and has two main strengths. First$1 y$, the cause-effect diagram is developed jointly by the research team members so does not reflect one person's opinion (researcher triangulation) and secondly, by adopting a holistic/systems perspective of the focal company, specific issues are combined to provide a complete 'rich picture' of the focal company situation. This is useful for the final feedback session when clarification and endorsement are sought from the company staff involved in the study.

QSAM has been shown to have international application, with investigations to-date in: Germany, New Zealand, the Netherlands, Thailand and the UK. This is significant because meaningful cross-industry/cross-national comparisons of supply chain performance are almost impossible using quantitative techniques alone, due to there often being questionable external validity. This can lead to attempts to 'compare apples with oranges'.

\section{Moving QSAM towards Design Sciences}

The fundamental basis for Quick Scan is in line with the origin of supply chain management and is presented on the left hand site of Figure 4 termed as the Systems Concept. Using Quick Scan as a method, the Systems Concept anchored in the integrated knowledge flywheel has been extended to the healthcare industry as well as the engineering to order sector.

In Figure 4 process improvement is initiated through an effective action flywheel, where process auditing plays a critical part, because audits provide the critical foundation for improvement projects. Those two flywheels are linked via system engineers (research team) who regularly observe, select, link, adapt and extend both flywheels by engaging in the art and technique of building practical, innovative, working systems, artefacts and organizations.

The learn-do improvement pathway to value stream optimisation shown in Figure 4 corresponds broadly with the description of performance betterment within a pro-active Toyota Production System (TPS) regimen as described by Spear and Bowen, (1999). As the latter showed in their classic paper on the DNA of TPS, success is enabled via a thorough understanding of Toyota principles, and practice. Further Böhme, Deakins, Pepper, and Towill (in press) reinforces the point of in-depth understanding of context being crucial to make TPS work in different settings. As stated before, QSAM researchers recognise the need for adapting conceptual knowledge to the context of use. Since the system of Theory and the system of Practice abide to different rules and 
operate in different social context, it is not possible to directly apply scientific knowledge in practical situations (Rasche \& Behnam, 2009). On the contrary, scientific knowledge needs to be reconstructed and re-designed to fit the logic and the requirements of business organisations (Rasche \& Behnam, 2009). For instance, Benders and Van Bijsterveld (2000) highlighted that lean implementation in German companies had little similarity with the original concept presented in Womack, Jones, and Roos (1990). As a consequence the 'Lean' concept was not directly translated from theory to practice but rather was used as a foundation for general restructuring activities (Rasche \& Behnam, 2009).

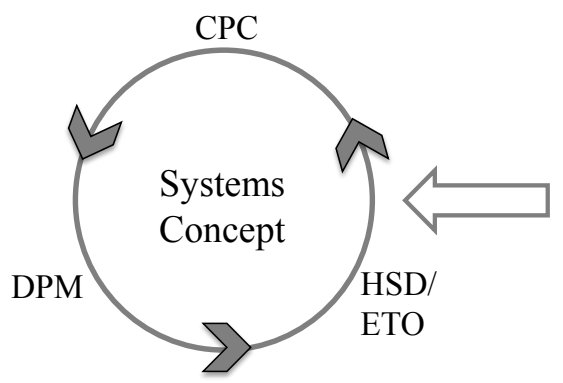

Integrated $\underline{\text { Knowledge Flywheel }}$

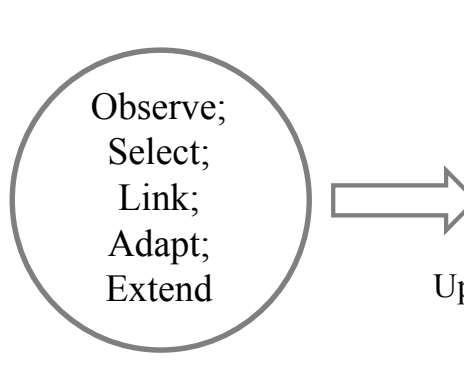

Engineering The Means Whereby

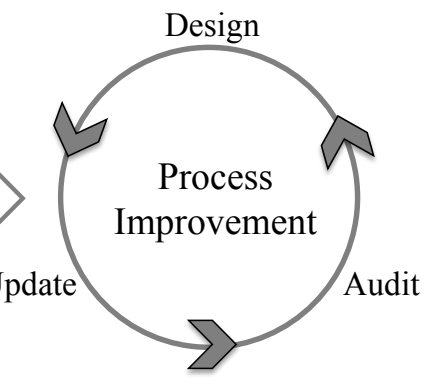

Effective Action Flywheel

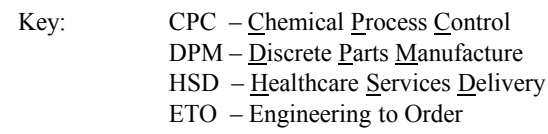

\section{Figure 4: Learn-Do Optimisation Pathway}

Böhme, Deakins, Pepper, and Towill (in press) present one action flywheel conducted in the New Zealand engineering-to-order sector aiming to understand how BPR principles enable streamlining of production and innovation capability enhancement. One action flywheel has been completed resulting in an increased understanding of the implementation of systems thinking in the New Zealand ETO sector. The action flywheel was judged successful through translation, adaptation, and linkages of the systems concept to an engineering to order company. Table 1 presents the impact of the effective action flywheel for the organisation Details about theory adaptation can be found in Böhme, Deakins, Pepper, and Towill (in press).

Table 1 - Improvement in ETO performance achieved using BPR

\begin{tabular}{ll}
\hline Performance metric & Recorded improvement \\
\hline Manufacturing costs & Reduced by 20 percent \\
Material movements & Reduced by 75 percent \\
Production lead time & Reduced by 65 percent \\
Work in Progress & Reduced by 70 percent \\
Adherence to schedule & Increased by 20 percent \\
Productivity & Increased by 100 percent \\
Process ownership & 'Much improved' \\
Innovation capability & 'Much improved' \\
Career enhancement opportunities & Increased via job rotation \& re- \\
& quirement for multi-skills \\
\hline
\end{tabular}

Source: adapted from Böhme, Deakins, Pepper, \& Towill (in press) 


\section{Discussion}

Over the last 30 years there has been growing concern and debate about the adequacy of research methods in the social sciences. In particular, methods derived from the natural sciences have been dominating the field (Gummesson, 2006; Morgan, 1980). Quantitative research is appointed superior to qualitative research and traditional natural sciences are hailed by social scientists as the role model for rigorous and objective research (Gummesson, 2006). However, the rigour and objectivity of these traditional methods has been questioned by Scandura and Williams (2002) and Gummesson (2006) since quantitative methods fall short in handling management complexity, fail to place variables into context and seldom incorporate human and social properties. Philosophically this dominant view is a concern because supply chain and logistics management generally takes place within the context of constant change and involves consideration of multiple layers of complexity, of component subsystems and personal relationship nuances that make posited generalisations and hypotheses very difficult to substantiate. An obstacle is thereby created when attempting to develop well-substantiated theories (Stuart, McCutcheon, Handfield, McLachlin, \& Samson, 2002).

The QSAM adheres to this approach and aims to help practitioners in designing effective solutions to context-specific organisational problems. In line with Rasche and Behnam's view (2009), the QSAM researchers recognise that it is not feasible to apply in practice SCM theories 'as they are', rather it is necessary to tailor them to the context of use. As a result, QSAM scholars identify the detachment between theory and practice neither as a knowledge creation nor knowledge transfer problem but as a knowledge adaptation (lost after translation) problem. By means of selecting, linking and adapting SCM theories into a specific organisation, QSAM researchers seek two concurrent objectives: enhancing scholars' understanding of how SCM theories are (or can be) applied in practice and also helping focal companies in implementing improvement programs within their organisations.

QSAM as presented here is described as an example of a mixed-methods approach that has proven to be extremely valuable for studying messy, complex, real-world supply chains. Philosophically it provides an interpretive perspective; one that emphasises the importance of subjective meanings and social-political and symbolic actions in the processes through which humans construct and reconstruct their reality. When conducting an action flywheel (implementation science), the deductive -inductive approach of QSAM strengthens understanding of links between theory and practice. This approach is essential in order to link experience (i.e. observations made in case company) with contemporary theory. This link aids in the observation, analysis and understanding of causal relationships between behaviour, variables and outputs within the supply chain, enabling researchers and practitioners to design effective improvement pathways and initiatives with a sound theoretical basis.

\section{Conclusion}

It may well be true, as McGrath (1982) stated that it is not possible to conduct an unflawed study. Every research method has inherent flaws and the choice of that method will limit the conclusions that can be drawn. It is therefore essential to obtain correlating evidence from using a variety of methods (Scandura \& Williams, 2000). Additionally researchers are increasingly questioned for their research relevance and impact due to the fact that many management theories are unimplementable (Beer, 2001). Hence, the solution in this case can be producing publications that can easily be accessed by practitioners (Clark \& Fincham, 2009), or require academics to specify how their research findings can be applied in practice (Beer, 2001).

QSAM provides a sounding investigation method that is also strongly underpinned by theory, and is well specified and communicated to practitioners. The initial deductive observations and analy- 
sis provide a solid foundation for an inductive process of identifying patterns and regularities to pursue and extend our understanding of the case/problem being examined. This may then lead to broader contributions to literature regarding the understanding of supply chain uncertainty, performance and analysis through auditing techniques; and ultimately reducing the practitioner academia relevancy gap.

\section{References}

Azorin, J. M., \& Cameron, R. (2010). The application of mixed methods in organisational research: A literature review. The Electronic Journal of Business Research, 8(2), 95-105.

Beach, R., Muhlemann, A. P., Price, D. H. R., Paterson, A., \& Sharp, J. A. (2001). The role of qualitative methods in production management research. International Journal of Production Economics, 4, 201 212 .

Beer, M. (2001). Why management research findings are unimplementable: An action science perspective. Reflections: The SoL Journal, 2 (3), 58-58.

Benders, J., \& Van Bijsterveld, M. (2000). Leaning on lean: The reception of management fashion in Germany. New Technology, 15, 50-64.

Berry, D., Naim, M. M., \& Towill, D. R. (1995). Business process reengineering An electronics products supply chain. IEE Proceedings for Science Measurement \& Technology, 142(5), 395-403.

Böhme, T., Childerhouse, P., Deakins, E., \& Towill, D. (2012). Reflections on interpretive management research. Journal of Leadership and Organisational Studies. 19(3), 369-377.

Böhme, T., Childerhouse, P., Deakins, E., Potter, A., \& Towill, D. R. (2008). Supply chain diagnosis. Operations Management, 34(2), 12-17.

Böhme, T., Deakins, E., Pepper, M., \& Towill, D. (in press). Systems engineering effective supply chain innovations. International Journal of Production Research [accepted manuscript].

Cascio, W. F. (2007). Evidence-based management and the market-place for ideas. Academy of Management Journal, 50, 1009-1012.

Carter, C. R., \& Ellram, L. M. (2003). Thirty-five years of The Journal of Supply Chain Management: Where have we been? The Journal of Supply Chain Management, Spring, 27-39.

Childerhouse, P., \& Towill, D. R. (2002). Analysis of the factors affecting real-world value stream performance. International Journal of Production Research, 40(15), 3499-3518.

Christopher, M. (1998). Logistics and supply chain management. London: FT Prentice Hall.

Clark, T. \& Fincham, R. (2009). Introduction: Can we bridge the rigour-relevance gap? Journal of Management Studies, 46(3), 510-515.

Edgehill, J. S., Olsmats, C., \& Towill, D. R. (1988). Industrial case study on the dynamics and sensitivity of a close-coupled production distribution system. International Journal of Production Research, 26(10), 1681-1693.

Edwards, P., \& Ram, M. (2006). Surviving on the margins of the economy: Working relationships in small, low-wage firms. Journal of Management Studies, 4(4), 67-83.

Eisenhardt, K. M. (1989). Building theories from case study research. Academy of Management Review, 14(4), 532-550.

Fawcett, S. E., \& Magnan, G. M. (2002). The rhetoric and reality of supply chain integration. International Journal of Physical Distribution \& Logistics Management, 32(5), 339-361.

Fawcett, S. E., Ellram, L. M., \& Ogden, J. A. (2007). Supply chain management: From vision to implementation. New Jersey: Pearson Prentice Hall. 
Flynn, B. B., Huo, B., \& Zhao, X. (2010). The impact of supply chain integration on performance: A contingency and configuration approach. Journal of Operations Management, 28, 58-71.

Flynn, B. B., Sakakibara, S., Schroeder, R. G., Bates, K. A., \& Flynn, E. J. (1990). Empirical research methods in operations management. Journal of Operations Management, 9(2), 250-284.

Frankel, R., Naslund, D., \& Bolumole, Y. (2005). The "white space" of logistics research: A look at the role of methods usage. Journal of Business Logistics, 26(2), 185-209.

Gummesson, E. (2006). Qualitative research in management: Addressing complexity, context and persona. Management Decision, 44(2), 167-179.

Halldorsson, A., Larson, P. D., \& Poist, R. F. (2008). Supply chain management: A comparison of Scandinavian and American perspectives. International Journal of Physical Distribution \& Logistics Management, 38(2), 126-142.

Hambrick, D. C. (2007), The field of management's devotion to theory: Too much of a good thing? The Academy of Management Journal, 50(6), 1346-1352.

Jelinek, M., Romme, A. G. L. \& Boland, R. J. (2008). Introduction to the special issue organization studies as a science for design: creating collaborative artifacts and research. Organization Studies, 29(3), 317329.

Jick, T. (1979). Mixing qualitative and quantitative methods: Triangulation in action. Admin Science Quarterly, 4, 602-611.

Kay, J. A. (2004). Culture and prosperity: The truth about markets : Why some nations are rich but most remain poor. New York: HarperBusiness.

Kieser, A. \& Leiner, L. (2009). Why the rigour-relevance gap in management research is unbridgeable. Journal of Management Studies, 46(3), 516-533.

Kotzab, H. (2005). The role and importance of survey research in the field of supply chain management. In H. Kotzab, S. Seuring \& G. Reiner (Eds.), Research methodologies in supply chain management (pp. 125-137). Heidelberg, Germany: Physica-Verlag.

Lawrence, P. R., \& Losch, J. W. (1967). Organisation and environment. Cambridge MA: Harvard University Press.

Luhmann, N. (1995). Social Systems. Stanford, CA: Stanford University Press.

Luhmann, N. (2005). The concept of autopoiesis. In D. Seidl \& K. H. Becker (Eds.), Niklas Luhmann and organization studies (pp. 54-63). Kristiandad: Liber and Copenhagen Business School Press.

McGrath, J. (1982). Dilemmatics: The study of research choices and dilemmas. In J. McGrath, J. Martin \& R.A. Kulka (Eds), Judgment calls in research (pp. 69-129). Newbury Park, CA: Sage.

Mentzer, J. T., \& Kahn, K. B. (1995). A framework of logistic research. Journal of Business Logistics, $16(1), 231-250$.

Meredith, J. (1998). Building operations management theory through case and field research. Journal of Operations Management, 16, 441-454.

Morgan, G., \& Smircich, L. (1980). The case of qualitative research. The Academy of Management Review, $5(4), 491-500$.

Näslund, D. (2002). Logistics need qualitative research - Especially action research. International Journal of Physical Distribution \& Logistics Management, 32(5), 321-338.

New, S. J., \& Payne, P. (1995). Research frameworks in logistics: Three models, seven dinners and a survey. International Journal of Physical Distribution \& Logistics Management, 25(10), 60-77.

Parnaby, J. (1979). Concept of a manufacturing system. International Journal of Production Research, $17(2), 123-135$. 
Poirier, C. C., \& Quinn, F. J. (2003). A survey of supply chain progress. Supply Chain Management Review, 7(5), 40-47.

Rasche, A., \& Behnam, M. (2009). As if it were relevant: A systems theoretical perspective on the relation between science and practice. Journal of Management Inquiry, 18(3), 243-255.

Rousseau, D. M., \& Hodgkinson, G. P. (2009). Bridging the rigour-relevance gap in management research: It's already happening. Journal of Management Studies, 46(3), 534-546.

Scandura, T. A., \& Williams, E. A. (2000). Research methodology in management: Current practices, trends, and implications for future research. Academy of Management Journal, 43(6), 1248-1264.

Scott, W. R., \& Cole, R. (2000). The quality movement and organisational theory. Thousand Oaks: Sage.

Seuring, S. A. (2005). Case study research in supply chains - An outline and three examples. In H. Kotzab, S. Seuring, \& G. Reiner (Eds.), Research methodologies in supply chain management (pp. 235-250). Heidelberg, Germany: Physica-Verlag.

Shapiro, D. L., Kirkman, B. L., \& Courtney, H. G. (2007). Perceived causes and solutions of the translation problem in management research. The Academy of Management Journal, 50(2), 249-266.

Simon, H. A. (1967). The sciences of the artificial. Cambridge, MA: MIT Press

Starkey, K., Hatchuel, A. \& Tempest, S. (2009). Management research and the new logics of discovery and engagement. Journal of Management Studies, 46(3), 547-558.

Stuart, I., McCutcheon, D. M., Handfield, R. B., McLachlin, R., \& Samson, D. (2002). Effective case research in operations management: A process perspective. Journal of Operations Management, 20, 419433.

Thompson, J. D. (1967), Organisations in action, New York, NY: McGraw-Hill.

Towill, D. R., Childerhouse, P., \& Disney, S. (2002). Integrating the automotive supply chain: Where are we now? International Journal of Physical Distribution \& Logistics Management, 32(2), 79-95.

Towill, D. R., \& Christopher, M. (2007). Do not lean too far - Evidence from the first decade. International Journal of Agile Systems and Management, 2(4), 406-424.

Tranfield, D., Denyer, D., \& Smart, P. (2003).Towards a methodology for developing evidence-informed management knowledge by means of systematic review. British Journal of Management, 14(3), 207207.

Van De Ven, A. H., \& Johnson, P. E. (2006). Knowledge for theory and practice. The Academy of Management Review, 31(4), 802-821.

Westbrook, R. (1994). Action research: A new paradigm for research in production and operations management. International Journal of Operations and Production Management, 15(12), 6-20.

Womack, J. P., Jones, D. T., \& Roos, D. (1990). The machine that changed the world. New York: Rawson.

Zailani, S., \& Rajagopal, P. (2005). Supply chain integration and performance: US versus East Asian companies. Supply Chain Management: An International Journal, 10(5), 379-393. 


\section{Biographies}

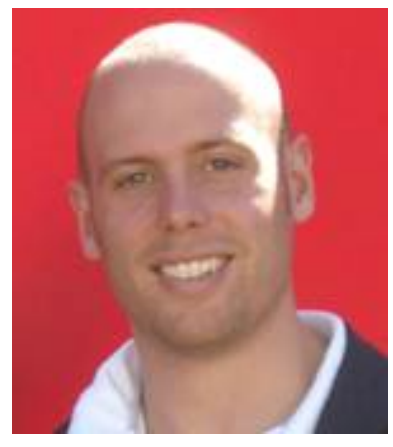

Dr Tillman Böhme ( $\mathrm{PhD}, \mathrm{MBA})$ is a lecturer at the University of Wollongong (Sydney Business School). Tillmann's particular research interest is supply chain integration in practice; more specifically the human, relationship, and cultural aspects of supply chain management and the development of potential pathways to enhancement. Tillmann belongs to a team of global researchers constantly seeking supply chain best practices and world class business solutions.

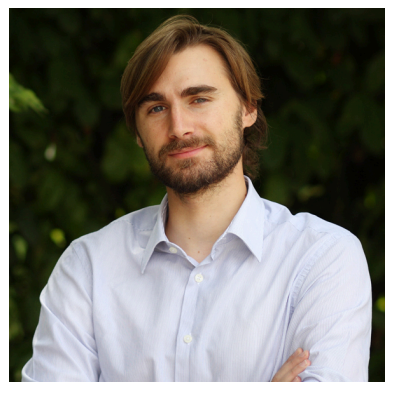

Alberto Ordigoni is a $\mathrm{PhD}$ student at the University of Wollongong. $\mathrm{He}$ has a Bachelor of Economics from the Ca' Foscari University of Venice, a Master of Economics from the University of Udine and a Master of International Business from the University of Wollongong. His $\mathrm{PhD}$ thesis will focus on supply chains within industrial clusters.

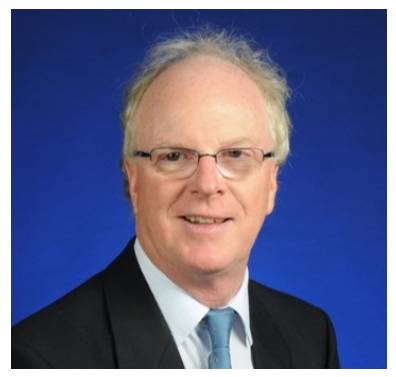

Dr Eric Deakins is an Associate Professor at the University of Waikato Management School in Hamilton, New Zealand. He has some 30 years of professional experience in the UK, USA, and New Zealand that spans technology management, business consulting, and tertiary level academe. His experience and scholarship predominantly relates to the business process improvement disciplines, with current research interests in the areas of: supply chain integration, ICT adoption and use, and e-government. 